\title{
Desempenho aerodinâmico de perfis NACA de quatro dígitos em aerogeradores de pequeno porte para a agricultura familiar
}

\section{Aerodynamic performance of NACA four-digit profiles in small- scale wind turbines for small farms}

\author{
Paulo Alexandre Costa Rocha ${ }^{1}$; Daniel Albiero ${ }^{2 *}$; \\ Marcos Paulo Gomes Fernandes ${ }^{3}$; Jefferson Lemos Fernandes ${ }^{4}$
}

\begin{abstract}
Resumo
No Brasil existem muitos locais que não são têm acesso a energia elétrica, principalmente em áreas rurais de agricultura familiar. Isto tem acentuado a importância da utilização de fontes de energia renováveis, como a energia eólica. Este trabalho consistiu no projeto, construção e teste de campo de duas pequenas turbinas eólicas de três pás, utilizando dois perfis aerodinâmicos diferentes. O objetivo foi comparar a influência destes perfis no desempenho aerodinâmico das turbinas. Com a Teoria do Momento do Elemento de Pá (BEM), duas turbinas eólicas de pequeno porte foram projetadas e construídas, tento como diferencial os perfis aerodinâmicos utilizados em sua seção: NACA 0012 (simétrico) e 4412 (cambado). Os resultados obtidos em campo, depois de analisados através de métodos estatísticos apropriados, demonstraram que os desempenhos das turbinas são similares em faixas de rotação próximas à de projeto $(\lambda=5)$. No entanto, em rotações abaixo e acima do projetado o perfil NACA 4412 tem desempenho superior.
\end{abstract}

Palavras-chave: Energia Eólica, perfil aerodinâmico, aerogerador de pequeno porte

\begin{abstract}
In Brazil, there are many places that do not have access to electric energy, mainly in rural areas with small farms. This situation has accentuated the importance of renewable energy sources, such as wind energy. This work consisted of the design, construction and field testing of two small three-bladed wind turbines with two different aerodynamic profiles. The aim of the study was to compare the profile influence on the turbine aerodynamic performance. Using the blade element momentum (BEM) theory, two wind turbines were designed and built with different cross-section aerodynamic profiles (NACA 0012 (symmetric) and 4412 (chambered)). Following statistical analysis, the results of the field tests demonstrated that the performances of the turbines are similar when the rotational speed is near the designed value $(\lambda=5)$. However, when the rotational speed is under or above the designed value, the NACA 4412 profile yields superior performance.
\end{abstract}

Key words: Wind energy, aerodynamic profile, small-scale wind turbine

1 Prof. Dr. de Engenharia Mecânica, Dept ${ }^{\circ}$ de Engenharia Mecânica da Universidade Federal do Ceará, DEM/UFC, Fortaleza, CE, Brasil. E-mail: paulo.rocha@ufc.br

2 Prof. Dr. de Engenharia Agrícola, Dept ${ }^{\circ}$ de Engenharia Agrícola, DENA/UFC, Fortaleza, CE, Brasil. E-mail: dalbiero@ufc.br

3 M.e em Engenharia Mecânica da Petróleo Brasileiro S.A., PETROBRAS, Macaé, RJ, Brasil. E-mail: marcospgf@gmail.com

4 Eng ${ }^{\circ}$ Mecânico, DEM-UFC, Fortaleza, CE, Brasil. E-mail: jeffengmecanica@gmail.com

* Author for correspondence 


\section{Introduction}

The cost and consequences of using traditional forms of energy have been under consideration in recent decades. In addition, there are many places in Brazil that are not served by electrical grids or where electricity is very costly, especially on small farms in rural areas. These factors increase the importance of so-called alternative energy sources, such as wind and solar energy (OLIVEIRA et al., 2008; CRAWFORD, 2009).

Among the reasons that justify the use of wind energy are its use to generate electricity in locations not served by the traditional distribution networks, which is the current situation of many municipalities in Brazil, especially in rural areas of the northeast region. In other cases, the population has access to the networks, but the electricity cost is so high that small farmers cannot use it. The northeast region experiences strong winds in the coastal areas of the states of Rio Grande do Norte, Ceará, Piauí and Maranhão as well as on an inland strip from the coast of Piauí to the north of the state of Minas Gerais (EPE, 2011). However, winds are not strong in the central region. Thus, it is necessary to study airfoil design aiming to adequately adapt to the wind characteristics of different regions. A way of using the wind potential to meet the requirements of these localities is with small-sized equipment that can supply local demand in a simple, cost-effective manner. In addition, studies must be conducted at the regional level to promote the more efficient use of resources and to assess the viability of the installation of wind turbines (ROCHA et al., 2012). A preliminary analysis was performed to determine the variation, annual regime and magnitude of the wind currents (GABRIEL FILHO et al., 2011).

Following the completion of that analysis, this study consisted of the design, construction and field testing of two small three-bladed wind turbines using NACA 0012 and NACA 4412 profiles to compare the influence of the aerodynamic profiles on the turbines' performance.

\section{Materials and Methods}

\section{Blade design}

The dimensions of the wind generators' blades were calculated by the blade element momentum (BEM) theory (MANWELL; MCGOWAN; ROGERS, 2002; VITALE; ROSSI, 2008a, 2008b) for each airfoil used. The performance of each blade was plotted in a power coefficient (Pc) vs. tip speed ratio $(\lambda)$ plot, and these results were then compared by statistical analysis.

To extract all the available wind power, all the wind kinetic energy would have to be extracted; in other words, the airflow would have to be stopped, which is unfeasible. Therefore, only a percentage of the available wind power can be extracted. This value is called the power coefficient $(\mathrm{Pc})$.

$$
C p=\frac{\text { Extracted } \cdot \text { Power }}{\text { Available.Power }}=\frac{T \cdot \Omega}{(1 / 2) \rho \cdot U^{3} \cdot \pi \cdot R^{2}}
$$

where T - Torque [N.m]

$\Omega$ - Rotor angular speed $[\mathrm{rad} / \mathrm{s}]$

$\rho-$ Fluid density $\left[\mathrm{kg} / \mathrm{m}^{3}\right]$

$\mathrm{U}-$ Wind speed $[\mathrm{m} / \mathrm{s}]$

$\mathrm{R}$ - Rotor radius $[\mathrm{m}]$

The tip speed ratio $(\lambda)$ is the ratio between the linear speed of the blade tip and the wind speed.

$$
\lambda=\frac{\omega \cdot R}{U}
$$

If the blade is divided into $\mathrm{N}$ parts, each one will receive airflows with different characteristics, as they have different rotational speeds ( $\omega r$ ), chord lengths and twist angles.

The BEM theory is based on the calculation of the flow for each one of the parts of the blade. The resultant speed of the element comprises the wind speed with the rotation of the blade itself, as shown 
in Figure 1 (a); this speed can be calculated by the and the drag force is following formula:

$$
w=\sqrt{U_{\infty}^{2}(1-a)^{2}+\Omega^{2} \cdot r^{2}\left(1+a^{\prime}\right)^{2}}
$$

The forces acting on the element can be calculated, as per Figure 1(b):

where the lift force on the element is

$$
\partial L=\frac{1}{2} . \rho \cdot W^{2} . c . C \cdot \delta r
$$

$$
\partial D=\frac{1}{2} \cdot \rho \cdot W^{2} \cdot c \cdot C_{d} \cdot r \delta r
$$

where $\mathrm{C}$ and $\mathrm{Cd}$ are the lift and drag coefficients of the airfoil, respectively.

The flow acts at an $\varphi$ angle relative to the rotor disk plane:

$$
\begin{aligned}
& \sin \phi=\frac{U(1-a)}{w} \\
& \cos \phi=\frac{\omega \cdot r\left(1+a^{\prime}\right)}{w}
\end{aligned}
$$

Figure 1. (a) Acting speeds, (b) forces acting on the blade element.

(a)

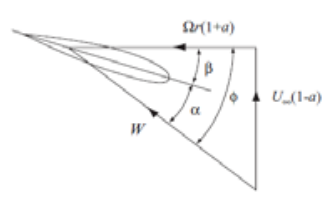

Source: Manwell, Mcgowan and Rogers (2002). (b)

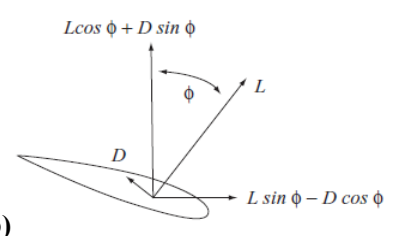

\section{Construction of the blades}

The following materials were used in the construction phase: 12 balsa wood sheets, three 1.5-m-long aluminum U-profiles, three solid square aluminum profiles for structural reinforcement, white cardstock, resin, nails, glue, screws and a steel disk to fasten the blades.

Twenty sections were drawn and printed (according to the BEM theory) using computeraided engineering (CAE) Solid Edge ST2 software. In addition to the outer contour of the profiles, the drawing showed the location, format and twist of the square hole where the profile must pass through and guiding lines to better position the sections during assembly.
The drawings were cut out and glued on a balsa wood sheet. To ensure an identical cut of each section for all three blades, two other wood sheets were nailed to the first one. Two or more nails were applied to each section to guarantee that the three sheets held together during cutting. The sections were cut with a bench saw after the glue dried.

The cut sections were then drilled for mounting in the aluminum profiles. The location of the holes was chosen by structural convenience, in the widest part of the section, at $30 \%$ of the chord from the leading edge. The square aluminum profiles were fitted onto the U-profiles and were riveted (Figure 2a) to increase the blades' resistance to wind forces. 
Figure 2. (a) Fastening of the aluminum profiles, (b) assembly of the blade "skeleton", (c) covering of the blades with cardstock.

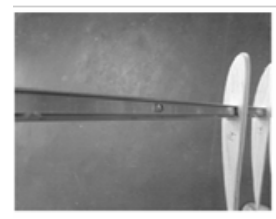

(a)

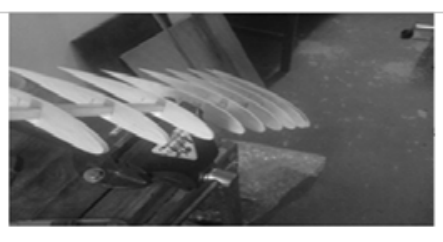

(b)

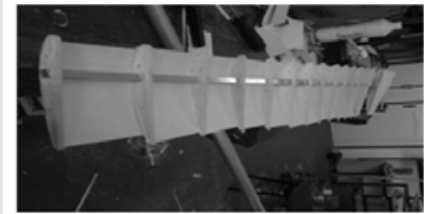

(c)

Source: Elaboration of the authors.

After the sections were cut, the blade "skeleton" was mounted on the aluminum profiles (Figure 2b).

The blades were then covered with cardstock (Figure 2c) and glue, and two coats of resin were applied to increase the rigidity. The blades were then screwed to the rotor disk.

\section{Field tests}

In the testing stage, the blades were mounted on a shaft where a torque transducer and a tachometer were previously installed. Figure 3 shows a schematic of the measurement and data acquisition system. Systems with a similar, simpler configuration have been successfully used in the past (ROCHA et al., 2010). The field tests were performed at the campus of the Federal University of Ceará (Universidade Federal do Ceará - UFC) in the Fortaleza-CE region.
In addition to the blade movement data, the wind speed was recorded using an ultrasonic anemometer based on the Doppler effect installed close to the main tower.

Data points (torque, rotation and wind speed) were obtained every second, and a minute-average was recorded in a data logger.

Each set of blades was tested on different days, $02 / 23 / 2011$ and $03 / 17 / 2011$. The blades were assembled and remained under testing for approximately seven hours, with measurements every second and averages recorded every minute. Only data with a mean wind speed above $1 \mathrm{~m} / \mathrm{s}$ were considered because there is no energy use below that speed.

Figure 4 shows the assembled and tested wind turbine.

Figure 3. Schematic of the measurement and data acquisition system.

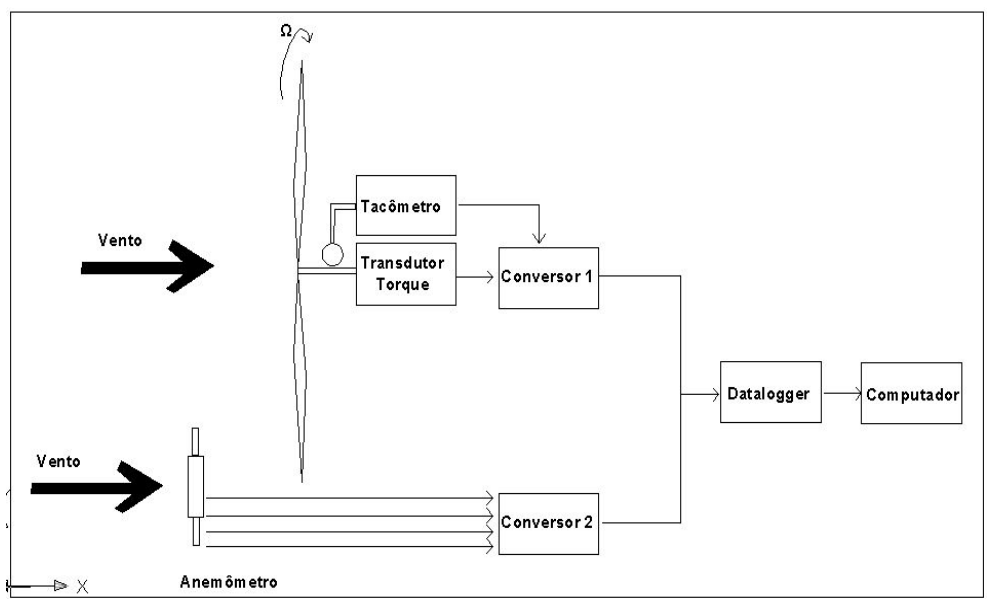

Source: Elaboration of the authors. 
Figure 4. Installed wind turbine.

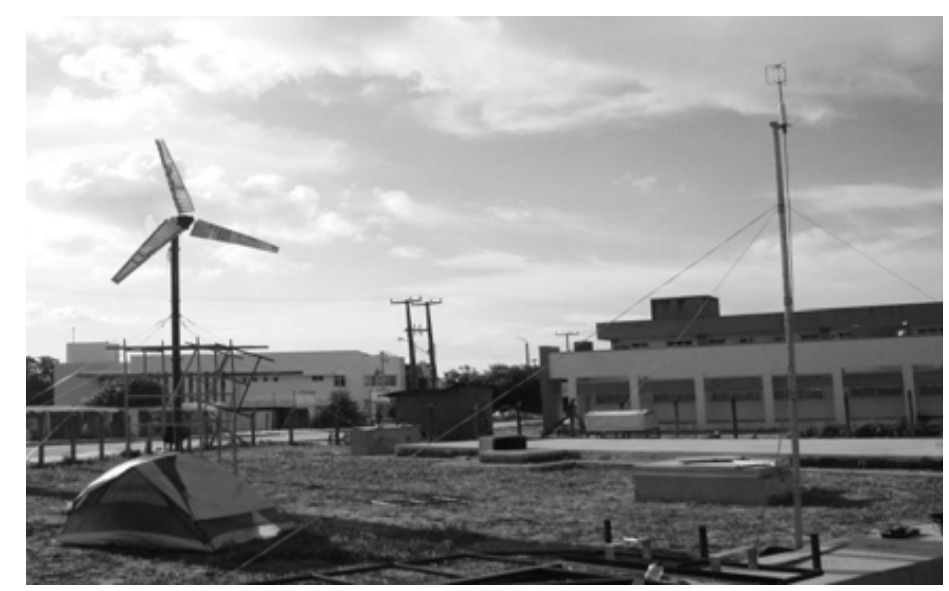

Source: Elaboration of the authors.

\section{Statistical data treatment}

Data were treated and evaluated by classical descriptive statistics (arithmetic mean, standard deviation, coefficient of variation, maximum, minimum, symmetry, and kurtosis). Kurtosis and symmetry tests were considered as normality tests for the distributions of the variables' measurements. According to Montgomery (2004), symmetry and kurtosis coefficients higher than 3 and lower than -3 represent a large deviation from the normal distribution; therefore, the hypothesis of normality must be rejected in those cases.

Furthermore, according to Montgomery (2004), sets of data that follow a normal distribution must be analyzed by hypothesis tests for the difference between the means using the F-test; this test considers that several treatment groups form the whole group and that the variance of the whole sample is partitioned into the variance within the whole group and the variance between the groups. Thus, the null hypothesis is rejected when the expected value of the square mean between groups is higher than the expected value of the square mean within each group. In that case, the F-statistic or F-ratio is higher than 1, always considering that the level of significance of the hypothesis is equal to or lower than the required level of significance $(\alpha)$. If there is a significant F-ratio at 5\% significance, the most powerful test to compare the means is the minimum significant difference (MSD) test, which analyzes all the differences between pairs of averages (MONTGOMERY, 2004).

In the case of data that did not fit a normal distribution, the statistical process control (SPC) method was used, based on control charts of the exponentially weighted moving average (EWMA). This methodology is widely used by Albiero et al. (2012) and Melo et al. (2013) and can be considered as a weighted average of all the observations in which the weights decrease geometrically with the observations. This method assigns less weight to more recent or less frequent observations, and its sensibility depends on the weight assigned to the interval between the limits and the average. Montgomery (2004) states that the EWMA is extremely robust regarding non-normality and is almost a non-parametric test, defined as follows:

$$
z i=\lambda \cdot \sum_{0}^{i-1}(1-\lambda) x_{i-j}+(1-\lambda)^{i} \cdot z o
$$


where zi is the value of the weighted moving average

$z o$ is the process target average

$x i$ is the value of the measured characteristic

$\lambda$ is the weight considered for the average, referring to the sensibility to capture small changes in the average.

\section{Results and Discussion}

Blade design

The blade geometry, tapering and twist are shown in Figures 5 to 8, which present the ratios between the blade tapering (length of the cross section) or twist and the distance from the root to the tip of the blade.

Figure 5. Plot of NACA 0012 blade tapering.

\section{Tapering}

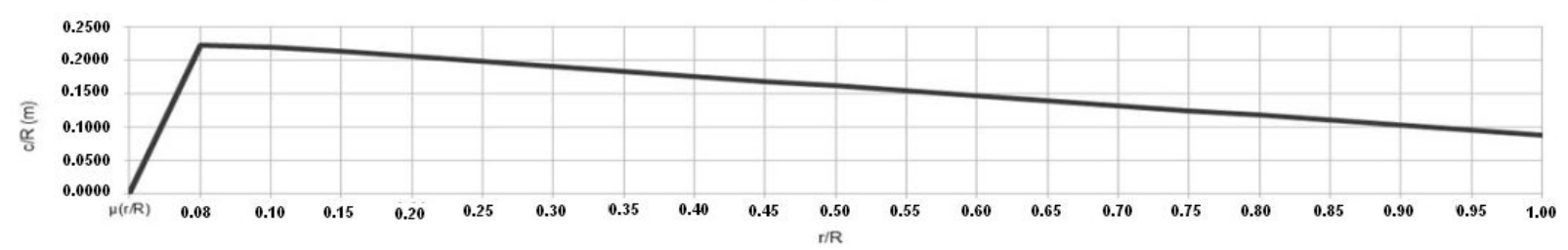

Source: Elaboration of the authors.

Figure 6. Plot of NACA 0012 blade twist.



Source: Elaboration of the authors.

Figure 7. Plot of NACA 4412 blade tapering.

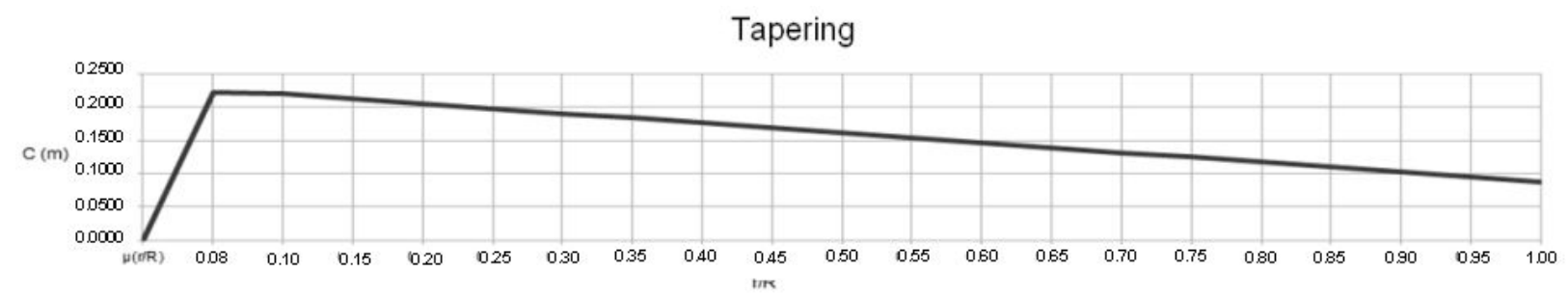

Source: Elaboration of the authors. 
Figure 8. Plot of NACA 4412 blade twist.

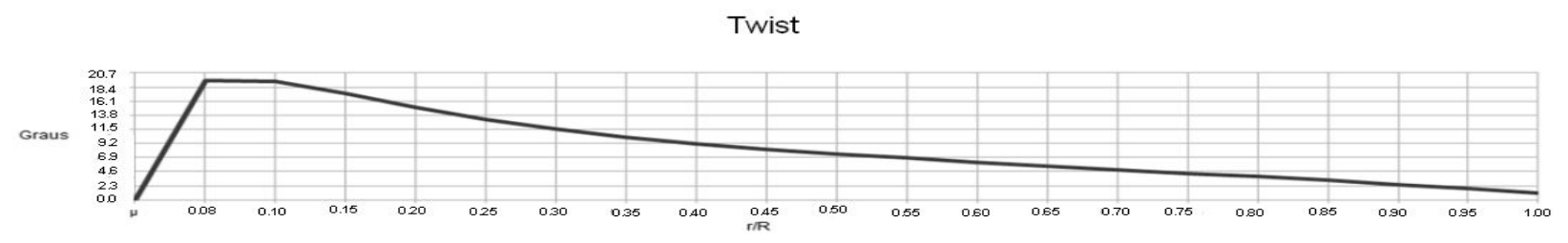

Source: Elaboration of the authors.

\section{Performance curves}

The performance curves of both turbines are shown in Figure 9. The error bars correspond to the $95 \%$ confidence intervals of Student's t test distribution for each range of the tip speed ratios (0.5 amplitude). Although the results are similar, a subtle superiority of the NACA 4412 blades can be noted. This was expected because the maximum $\mathrm{L} / \mathrm{D}$ (lift/drag) ratio of this profile is higher. The BEM theory assumes zero drag in the development of the design equations. Although this condition is hypothetical, it is increasingly approximated as the lift of the aerodynamic profile reaches higher values relative to the drag (MANWELL; MCGOWAN; ROGERS, 2002).

Figure 9. Performance curves of the tested turbines.

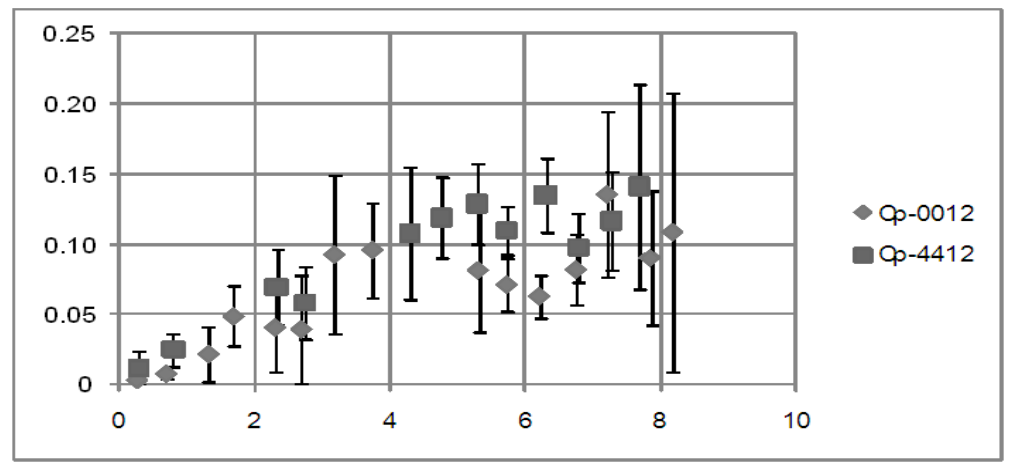

Source: Elaboration of the authors.

\section{Performance comparison}

The performance of the turbines was compared in terms of the presence of normality. One-way analysis of variance (ANOVA) was performed if the data were normally distributed. In the cases that lacked normality, the EWMA method was used. Table 1 shows the descriptive statistics of the turbines in the ranges of the tip speed ratios tested.
According to the symmetry and kurtosis tests in the 0 to 1 range of the tip speed ratio (considering a cutoff value of 3; MONTGOMERY, 2004), the distributions can be considered normal; therefore, ANOVA could be performed (Table 2).

Table 3 shows the comparison between the means by the MSD test. 
Table 1. Power coefficients $(\mathrm{Pc})$ of the turbines in the evaluated ranges of blade tip speed ratios.

\begin{tabular}{cccccccccc}
\hline $\begin{array}{c}\text { Pc } \\
\text { Range }\end{array}$ & Variable & Sample & Mean & S.D. & C.V. & Minimum & Maximum & Symmetry & Kurtosis \\
\hline \multirow{2}{*}{$0-1$} & NACA0012 & 46 & 0.0052 & 0.0043 & 82.79 & 0.0010 & 0.0194 & 1.64 & 2.55 \\
& NACA4412 & 19 & 0.0194 & 0.0174 & 89.79 & 0.0007 & 0.0621 & 1.06 & 0.49 \\
\hline \multirow{2}{*}{$1-3$} & NACA0012 & 24 & 0.0394 & 0.0264 & 67.04 & 0.0040 & 0.0887 & 0.38 & -1.17 \\
& NACA4412 & 12 & 0.0565 & 0.0231 & 40.88 & 0.0164 & 0.1020 & 0.34 & 0.36 \\
\hline \multirow{2}{*}{$3-4.5$} & NACA0012 & 14 & 0.1029 & 0.0806 & 67.50 & 0.0420 & 0.1250 & 2.55 & 7.70 \\
& NACA4412 & 14 & 0.0948 & 0.0509 & 53.68 & 0.0198 & 0.2106 & 0.86 & 0.67 \\
\hline \multirow{2}{*}{$4.5-5.5$} & NACA0012 & 12 & 0.0770 & 0.0556 & 72.12 & 0.0137 & 0.1835 & 0.62 & -0.86 \\
& NACA4412 & 15 & 0.1193 & 0.0519 & 43.51 & 0.0394 & 0.2076 & 0.27 & -0.71 \\
\hline \multirow{2}{*}{$5.5-6.5$} & NACA0012 & 29 & 0.0798 & 0.0752 & 94.29 & 0.0270 & 0.4407 & 4.19 & 20.21 \\
& NACA4412 & 29 & 0.1103 & 0.0445 & 40.33 & 0.0514 & 0.2344 & 1.04 & 1.64 \\
\hline \multirow{2}{*}{$6.5-7.5$} & NACA0012 & 20 & 0.1177 & 0.0815 & 69.23 & 0.0289 & 0.3647 & 1.60 & 3.29 \\
& NACA4412 & 18 & 0.1352 & 0.0535 & 39.60 & 0.0539 & 0.2557 & 0.74 & 0.42 \\
\hline \multirow{2}{*}{$7.5-8.5$} & NACA0012 & 8 & 0.0994 & 0.0462 & 46.51 & 0.0547 & 0.2003 & 1.72 & 3.35 \\
& NACA4412 & 8 & 0.1397 & 0.0410 & 29.31 & 0.0757 & 0.1948 & -0.34 & -0.88 \\
\hline
\end{tabular}

Source: Elaboration of the authors.

Table 2. ANOVA of the 0-1 range of the tip speed ratios.

\begin{tabular}{cccccc}
\hline & Degree of Freedom & Sum of Squares & Mean Squares & F & $\mathrm{p}$ \\
\hline Factor & 1 & 0.002732 & 0.002732 & 27.17 & 0.000 \\
\hline Error & 63 & 0.006335 & 0.000101 & & \\
\hline Total & 64 & 0.009067 & & & \\
\hline
\end{tabular}

Source: Elaboration of the authors.

Table 3. MSD test with 95\% significance for the aerodynamic profile variable.

\begin{tabular}{cccccc}
\hline Level & Number of Samples & Mean & Standard Deviation & & \\
\hline NACA0012 & 46 & 0.00521 & 0.00431 & $X$ & \\
\hline NACA4412 & 19 & 0.01946 & 0.01748 & & $\mathrm{X}$ \\
\hline
\end{tabular}

Source: Elaboration of the authors.

The results of Table 3 show that there is a significant difference between the airfoils in the 0 to $1 \lambda$ range. Because the tip speed ratios are still very low, the blade is almost still and is thus subjected to high angles of attack. As long as there is no stall, cambered profiles such as NACA 4412 have much better lift results than symmetric profiles (NACA 0012).
According to the symmetry and kurtosis tests (considering a cutoff value of 3; MONTGOMERY, 2004), in the 1 to 3 range of the tip speed ratio, the distributions can be considered normal; therefore, the ANOVA can be conducted (Table 4). 
Table 4. ANOVA of the 1-3 range of the tip speed ratios.

\begin{tabular}{cccccc}
\hline & Degree of Freedom & Sum of Squares & Mean Squares & $\mathrm{F}$ & $\mathrm{p}$ \\
\hline Factor & 1 & 0.002363 & 0.002363 & 3.66 & 0.064 \\
\hline Error & 34 & 0.021938 & 0.000645 & & \\
\hline Total & 35 & 0.024301 & & & \\
\hline
\end{tabular}

Source: Elaboration of the authors.

It can be observed from the ANOVA that there is no difference between the means (F-test $=3.66$ and $\mathrm{p}=0.064)$. However, the superiority of profile NACA 4412 persisted regarding the mean.

According to the kurtosis tests of airfoil NACA 0012, there is no normal distribution in the 3 to
4.5 range of the tip speed ratios. Therefore, it was not possible to perform ANOVA by the F-statistic (Table 1), and the EWMA method was used for the analysis (Figure 10).

Figure 10. EWMA plots for airfoils (a) NACA0012 and (b) NACA4412, considering the 3 to 4.5 range of the tip speed ratios.

(a)

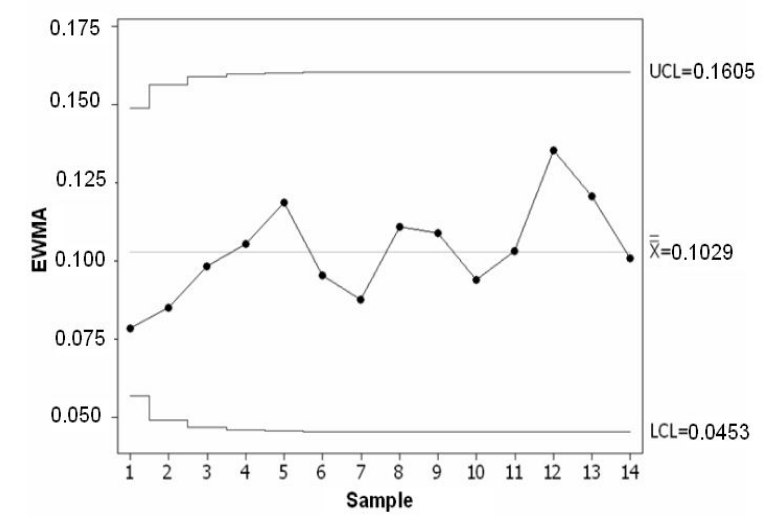

Source: Elaboration of the authors.

The plots show that in the $\lambda$ range from 3 to 4.5 , there is no difference between the airfoils. The amplitude of the EWMA variation around the mean for NACA 4412 (0.09) is absorbed by the amplitude of the EWMA variation of NACA 0012 (0.10); in other words, there is no difference between the means. Of note, the variability of the airfoil measurements is not high, which indicates stable measurement processes, a fact that is demonstrated when the plots do not move away from the mean and (b)

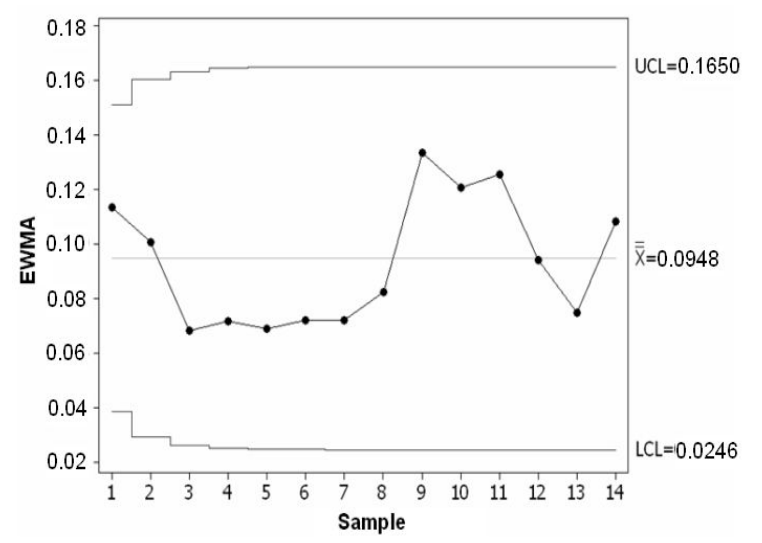

remain within the upper and lower control limits. This corroborates what was expected because the performance of the blades tends to become similar as they approach the design condition $(\lambda=5)$.

According to the symmetry and kurtosis tests (Table 1) (MONTGOMERY, 2004), in the 4.5 to 5.5 range of the tip speed ratios, the distributions can be considered normal; therefore, ANOVA can be performed (Table 5). 
Table 5. ANOVA of the 4.5 to 5.5 range of the tip speed ratios.

\begin{tabular}{cccccc}
\hline & Degree of Freedom & Sum of Squares & Mean Squares & F & P \\
\hline Factor & 1 & 0.01193 & 0.01193 & 4.16 & 0.052 \\
\hline Error & 25 & 0.07171 & 0.00287 & & \\
\hline Total & 26 & 0.08363 & & & \\
\hline
\end{tabular}

Source: Elaboration of the authors.

According to the ANOVA, it can be observed that there is no difference between the means, F-test $=4.16$ and $p=0.052$. Again, as expected, the results were similar because the design value of the tip speed ratio is exactly in the middle of the range.

According to the symmetry and kurtosis tests of airfoil NACA 0012, there is no normal distribution in the 5.5 to 6.5 range of the tip speed ratios. Therefore, it was not possible to perform ANOVA by the F-statistic (Table 1).

Figure 11. EWMA plots for airfoils (a) NACA0012 and (b) NACA4412, considering the 5.5 to 6.5 range of the tip speed ratios.

(a)

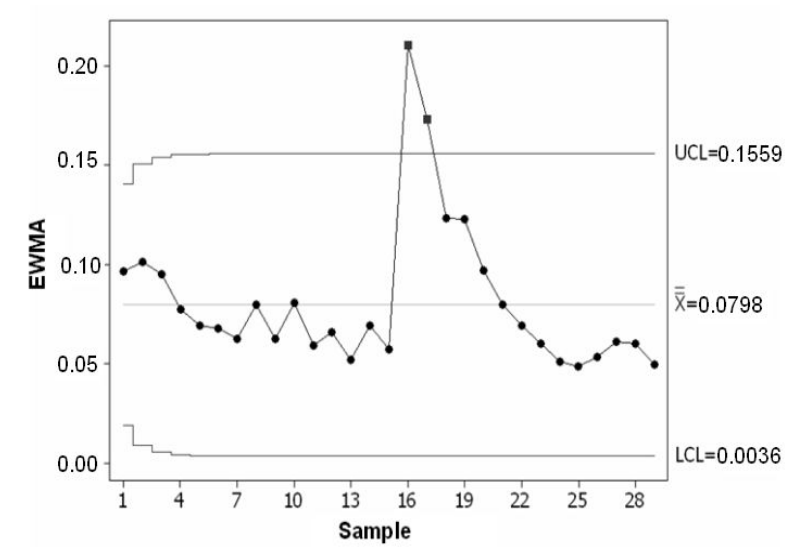

Source: Elaboration of the authors.

The turbines had a similar behavior in the ranges of the tip speed ratios close to the design value ( 3 to $4.5 ; 4.5$ to $5.5 ; 5.5$ to 6.5 ). This result was expected because the BEM theory designs blades for optimum performance according to
The plots in Figure 11 show that in the $\lambda$ range from 5.5 to 6.5 , there is no difference between the airfoils. The amplitude of the EWMA variation around the mean of NACA 0012 (0.07) is fully absorbed by the amplitude of the EWMA variation of NACA $4412(0.11)$; in other words, there is no difference between the means. Of note, the variability of the airfoil measurements is intense, as demonstrated by the instability of the measured processes; this is shown by the points outside of the EWMA upper limits ( 0.15 for NACA 0012 and 0.16 for NACA 4412).

(b)

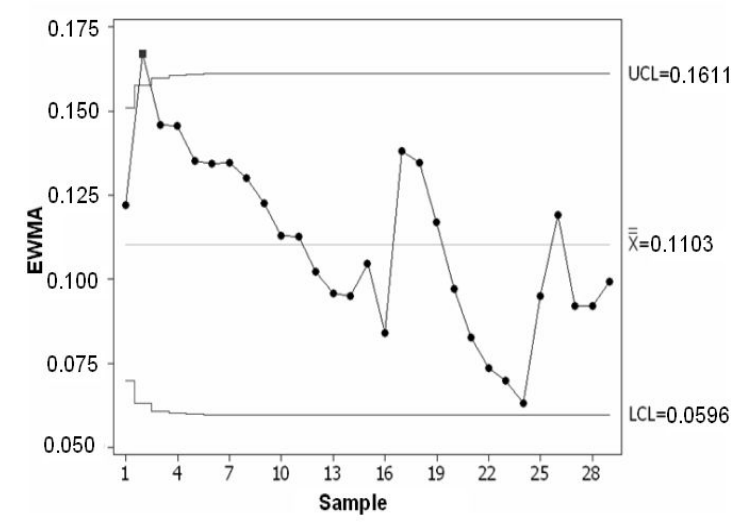

the aerodynamic characteristics of the profiles (MANWELL; MCGOWAN; ROGERS, 2002). It is at the starting (low rotation) and low torque (high rotation) conditions that the profiles will show significant differences between them. 
According to the kurtosis test of airfoil NACA 0012 , there is no normal distribution in the 6.5 to 7.5 range of the tip speed ratios. Therefore, it was not possible to perform ANOVA by the F-statistic (Table 1).

In Figure 12 the plots ofthe $\lambda$ range from 6.5 to 7.5 show that although there are a few points of intersection, in most cases, there is a difference between the airfoils. That is indicated by the fact that the amplitude of the EWMA variation around the mean of NACA $0012(0.11)$ is not fully absorbed by the amplitude of the EWMA variation of NACA 4412 (0.13).

Figure 12. EWMA plots for airfoils (a) NACA0012 and (b) NACA4412, considering the 6.5 to 7.5 range of the tip speed ratios.

(a)

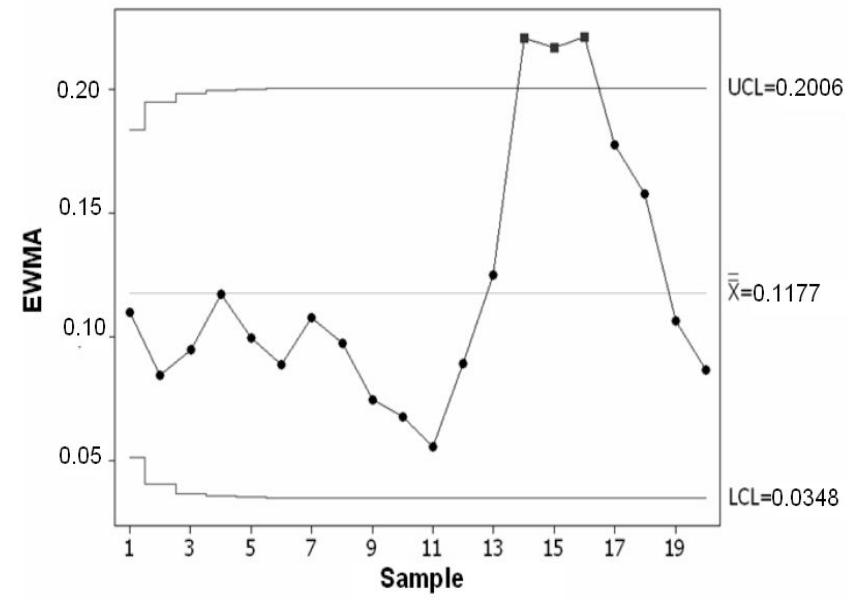

(b)



Source: Elaboration of the authors.

Therefore, there is a difference between the means. However, the measurement process of airfoil NACA 0012 is unstable, which generates high variability among the means. This indicates that there may be data intersection, but the plots show that in most of the points, there is low variability around the mean, so there is an actual difference between the airfoils. Thus, as expected, the performance of the blade designed with airfoil NACA 4412 was superior because it had a higher lift/drag ratio.

According to the kurtosis test of airfoil NACA 0012 , there is no normal distribution in the $\lambda$ range from 7.5 to 8.5. Therefore, it is not possible to perform ANOVA of the F-statistic (Table 1).
In Figure 13 the plots show a difference between the airfoils for the $\lambda$ range from 7.5 to 8.5 . The amplitude of the EWMA variation around the mean of NACA 0012 (0.09) is considerably different than the amplitude of the EWMA variation of NACA 4412 (0.13); in other words, the means are different. The plots show low variability around the mean, indicating an actual difference between the airfoils in addition to processes with stable measurements. Finally, profile NACA 4412 had a better performance within the blade operating range.

It is worth noting that there is a limit to the rotational speed $(\lambda>8.5)$ of the blades, even if the torque in the shaft is null. This occurs because there is a point at which aerodynamic drag does not allow further acceleration of the blade. 
Figure 13. EWMA plots for airfoils (a) NACA0012 and (b) NACA4412, considering the 7.5 to 8.5 range of the tip speed ratios.

(a)

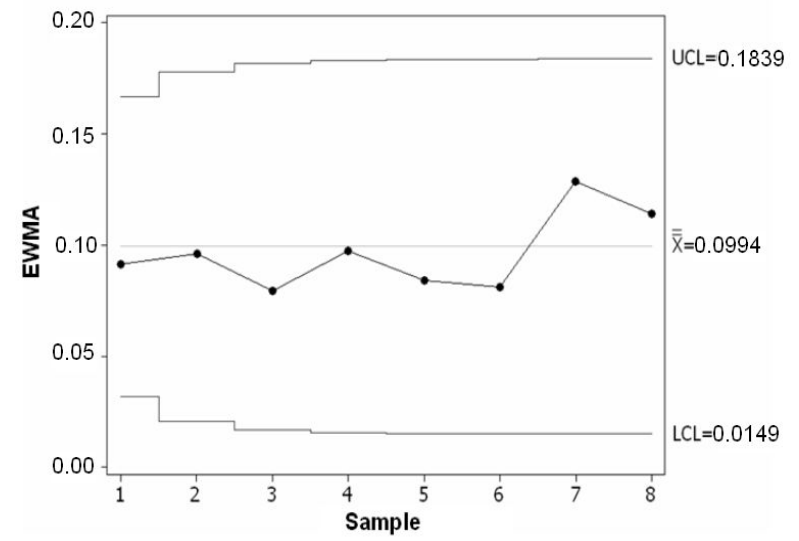

(b)

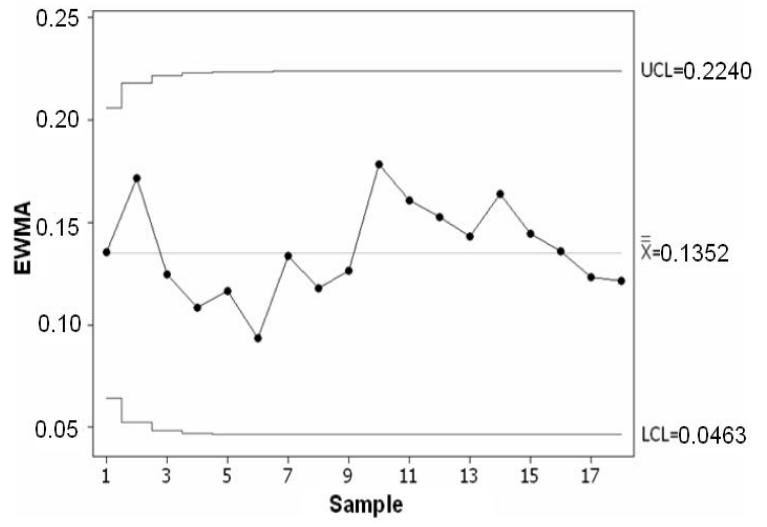

Source: Elaboration of the authors.

\section{Conclusions}

This comparative study established some design and construction parameters that allowed the improvement of the performance of small-scale wind turbines once the local wind conditions were known.

The blades had similar performances at rotational speed ranges close to that of the design condition $(\lambda=5)$. Thus, it is concluded that for different aerodynamic profiles, different geometries will be required to obtain the best result. The results at rotational speeds below and above the design condition showed the superiority of profile NACA 4412.

\section{References}

ALBIERO, D.; MACIEL, A. J. S.; MILAN, M.; MONTEIRO, L. A.; MION, R. L. Avaliação da distribuição de sementes por uma semeadora de anel interno rotativo utilizando média móvel exponencial. Revista Ciência Agronômica, Fortaleza, v. 43, n. 1, p. 8695, 2012.

CRAWFORD, R. H. Life cycle energy and greenhouse emissions analysis of wind turbines and the effect of size on energy yield. Renewable and Sustainable Energy Reviews, London, v. 13, n. 4, p. 2653-2660, 2009.
EMPRESA DE PESQUISA ENERGÉTICA - EPE. Plano decenal de energia 2019. Brasília: Ministério das Minas e Energia 2011. Disponível em: $<$ http://www.epe. gov.br>. Acesso em: 10 ago. 2011.

GABRIEL FILHO, L. R. A.; CREMASCO, C. P.; SERAPHIM, O. J.; CANEPPELE, F. D. Caracterização analítica e geométrica da metodologia geral de determinação de distribuições de Weibull para o regime eólico e suas aplicações Engenharia Agrícola, Jaboticabal, v. 31, n. 1, p. 56-66, 2011.

MANWELL, J.; MCGOWAN, J.; ROGERS, A. Wind energy explained. New York: Wiley, 2002. 570 p.

MELO, R. P.; ALBIERO, D.; MONTEIRO, L. A.; SOUZA, F. H.; SILVA, J. G. Qualidade na distribuição de sementes de milho em semeadoras em solo do semiárido cearense. Revista Ciência Agronômica, Fortaleza, v. 44, n. 1, p. 94-101, 2013.

MONTGOMERY, D. C. Introdução ao controle estatístico da qualidade. Rio de Janeiro: LTC, 2004. 570 p.

OLIVEIRA, L. F. C.; FERREIRA, R. C.; ALMEIDA, R. A.; LOBATO, R. J. V.; MEDEIROS, A. M. M. Potencial de redução do consumo de energia elétrica pela utilização de aquecedores solares no Estado de Goiás Engenharia Agrícola, Jaboticabal, v. 28, n. 3, p. 406-416, 2008.

ROCHA, P. A. C.; CARNEIRO, F. O.; LOPES, A. S.; MAIA, I. A.; MODOLO, A. B. Montagem e testes de uma bancada para medição de desempenho de aerogeradores em escala. Revista Brasileira de Ensino de Física, Porto Alegre, v. 33, n. 2, p. 2309-2314, 2010. 
ROCHA, P. A. C.; SOUSA, R. C.; ANDRADE, C. F.; SILVA, M. E. V. Comparison of seven numerical methods for determining Weibull parameters for wind energy generation in the northeast region of Brazil. Applied Energy, London, v. 89, n. 5, p. 395-400, 2012.
VITALE, A. J.; ROSSI, A. P. Computational method for the design of wind turbine blades. International Journal of Hydrogen Energy, v. 33, n. 13. p. 3466-3470, 2008a.

Software tool for horizontal-axis wind turbine simulation. International Journal of Hydrogen Energy, v. 33, n. 13, p. 3460-3465, 2008 b. 
